\title{
DAMPAK PERUBAHAN DARI POLA PERLADANGAN TERHADAP KESEJAHTERAAN PETANI TRANSMIGRAN LOKAL (Suatu Kasus di Wilayah Transmigrasi Umum Sabung SP 1 Kabupaten Sambas Provinsi Kalimantan Barat)
}

\author{
The Impact Of Changes From Shifting Cultivation Patterns On The Welfare \\ Of Local Transmigrant Farmers (in The Case Of A General Transmigration \\ Sabung Sp 1 District Sambas West Kalimantan Province)
}

\author{
Agus Warman \\ Universitas Padjadjaran \\ Email korespondensi :DR.AGUSWARMAN@Yahoo.co.id
}

\begin{abstract}
Abstrak
Salah satu upaya untuk meningkatkan kesejahteraan petani ladang berpindah adalah dengan cara mengubah pola pertanian mereka menjadi pola pertanian menetap di lokasi transmigrasi. Tujuan penelitian adalah : (1) Mengetahui keragaan fenomena interaksi sosial yang terjadi antara sesama petani transmigran lokal dan antara transmigran lokal dengan transmigran pendatang (2) Mengetahui proses introduksi dan adopsi inovasi baik yang diserap dari sesama petani atau pun dari penyuluh pertanian (3) Mengetahui pencapaian adopsi inovasi teknologi oleh petani transmigran lokal dan pengaruhnya terhadap tingkat pendapatan mereka (4) Mengetahui pengaruh serapan inovasi dari sesama petani dan sikap petani terhadap kegiatan penyuluhan; ketersediaan lembaga pendukung usahatani; serta potensi Internal keluarga tani terhadap adopsi inovasi teknologi petani transmigran lokal (5) Mengukur pencapaian kesejahteraan materil dan non materil petani transmigran lokal. Penelitian ini merupakan kasus di lokasi Transmigrasi Sabung SP 1 Kabupaten Sambas Provinsi Kalimantan Barat. Merupakan penelitian survey dan alat analisis yang digunakan adalah Path Analisis dan Uji Wilcoxon. Hasil penelitian mendapatkan bahwa : a) Berkembangnya sikap kompromistis b) Belum terbentuk kepemimpinan informal. c) Terbentuknya akulturasi dalam hal bahasa. d) Sikap petani transmigran lokal terhadap transmigran pendatang berkorelasi positif dengan rentang jarak sosial diantara mereka. e) Rentang jarak sosial berkorelasi positif terhadap kondisi tingkat keharmonisan interaksi sosial, namun tingkat keharmonisan interaksi sosial ini tidak berpengaruh terhadap aspek kesejahteraan non materil petani transmigran lokal f) Serapan inovasi teknologi petani transmigran lokal terkategori sangat rendah sampai rendah. g) Transmigran lokal dan transmigran pendatang secara timbal balik saling menyerap inovasi teknologi. Tingkat keharmonisan interaksi sosial antara mereka mempengaruhi tingkat serapan inovasi, sehingga berpengaruh terhadap tingkat adopsi inovasi oleh transmigran lokal. h) Tingkat serapan inovasi dari sesama petani lebih dominan dibanding serapan inovasi dari penyuluh. i) Tingkat adopsi inovasi transmigran lokal berpengaruh terhadap tingkat pendapatan usahatani, namun tidak berpengaruh terhadap tingkat pendapatan total mereka. j) Tingkat serapan inovasi dari sesama petani berpengaruh terhadap tingkat adopsi inovasi oleh petani transmigran lokal, namun sikap petani terhadap kegiatan penyuluhan, kondisi internal petani dan tingkat ketersediaan lembaga pendukung usahatani tidak berpengaruh terhadap adopsi inovasi petani transmigran lokal. k) Rerata tingkat pendapatan usahatani transmigran lokal sebelum mengikuti transmigrasi lebih besar dibanding setelah mengikuti transmigrasi. Tingkat pendapatan total mereka setelah mengikuti program transmigrasi lebih besar dibanding sebelum mengikuti transmigrasi. Tingkat kesejahteraan non materil petani lokal setelah mengikuti program transmigrasi berada pada kategori memuaskan dan sangat memuaskan.
\end{abstract}

Kata kunci : Perubahan pola pertanian, Transmigran lokal, Kesejahteraan materil, Kesejahteraan Non materil, Transmigrasi.

\begin{abstract}
One effort to improve the welfare of shifting cultivation farmers is a way to change the pattern of their farm into a pattern of sedentary agriculture in transmigration sites. The purpose of this study was to: (1) Determine the variability phenomenon of social interactions among local homesteader and between local homesteader with migrants (2) Knowing the introduction and adoption of innovations that are absorbed from fellow farmer or from agricultural extension (3) Knowing achieving the adoption of technological innovations by farmers and local homesteader influence on the level of their income (4) Determine the influence uptake of innovation among farmers and farmers' attitudes toward counseling activities; availability of farm support agencies; and the potential Internal family farm to adoption of technological innovations farmers through local homesteader (5) Measure the achievement of material and non-material well-being of migrants local farmers. This study was a case in Transmigration locations Sabung SP 1 Sambas district of West Kalimantan Province. Analysis tool used Path Analysis and Wilcoxon test. The results of the study found that: a) The development of an attitude of compromise b) are formed informal leadership. c) Establishment of acculturation in terms of language. d) The attitude of local farmers against migrants positively correlated with a range of social distance between them. e) The range of social distance positively correlated to the degree of harmony conditions of social interaction, but the level of social interaction of this harmony does not affect the welfare of the non-material aspects of local homesteader farmer f) Uptake local homesteader farmer technological innovation categorized very low to low. g) Local Transmigrants absorb technological innovation of migrants and vice versa. The level of harmony between their social interactions affect the rate of uptake of innovation, so that the effect on the rate of innovation adoption by local homesteader. $h$ ) The rate of uptake of innovation among farmers is more dominant than the uptake of innovation extension. i) The rate of adoption of innovation local homesteader affect the level of farm income, but do not affect the level of their total income. j) The rate of uptake of innovation among farmers affect the rate of adoption of innovations by farmers local homesteader, but the attitude of farmers to extension activities, the internal conditions of farmers and farm-level availability of supporting agencies had no effect on the adoption of a local homesteader farmer innovation. $k$ ) The mean level of farm income before following local transmigration transmigration greater than after following transmigration. The level of their total income after transmigration program bigger than before following transmigration. The level of non-material well-being of the local farmers after the transmigration program in the category satisfactory and very satisfactory.
\end{abstract}

Keywords: Changing patterns of farming, local Transmigran, material welfare, Non-material welfare, Transmigration. 


\section{Pendahuluan}

Michael R. Dove (1985), menyimpulkan bahwa sistem perladangan merupakan hasil adaptasi paling baik dan paling rasional yang dilakukan masyarakat adat, terhadap lingkungan alam dan sosialnya. Apa yang dikemukakan oleh Michael R. Dove di atas adalah realistis ketika kondisi daya dukung luasan lahan yang tersedia, relatif cukup tinggi dibanding kebutuhan luasan lahan yang dibutuhkan oleh penduduk desa hutan bagi kegiatan perladangan berpindahnya. Pada kondisi saat ini, di Indonesia khususnya, terjadi kecenderungan dimana jumlah penduduk desa hutan terus meningkat jumlahnya, namun di sisi lain justru terjadi penyempitan jumlah luasan lahan hutan yang dapat dikuasai untuk kegiatan perladangan mereka.

Menurut data Kementrian Negara Percepatan Pembangunan Daerah Tertinggal (PDT), di Indonesia saat ini terdapat 18.782 desa hutan atau sekitar $26,6 \%$ dari total seluruh desa yang ada di Indonesia, atau sebesar $58 \%$ dari jumlah total desa tertinggal yang ada di Indonesia (32.379 desa tertinggal). Jumlah total penduduknya mencapai 33.512.845 jiwa. Dari jumlah total penduduk desa hutan tersebut, jumlah keluarga yang menggantungkan $100 \%$ sumber bahan pangan melalui perladangan dan ekstraktif dari kawasan hutan adalah sebanyak 848.575 KK, $45 \%$ diantaranya masuk dalam kategori keluarga miskin (Krisnadi : 2010).

Terjadinya kondisi peningkatan jumlah penduduk dan makin menyempitnya luasan lahan yang dapat "dikuasai" untuk kegiatan perladangan padi, dialami juga antara lain oleh masyarakat Dayak di Provinsi Kalimantan Barat. Sejak ratusan tahun lalu, masyarakat dayak yang bermukim di kawasan hutan Kalimantan Barat telah mengembangkan sistem distribusi sumber daya alam, ekonomi dan politik berdasarkan hukum adat. Komunitas suku-suku adat dayak terhimpun dalam suatu komunitas Binua atau kampong yang bersifat Self governing community, dimana memiliki otonomi pengelolaan luasan hutan sendiri, bagi kepentingan pemenuhan setiap anggota komunitasnya, yang dikenal dengan istilah lahan Ulayat. Pada kondisi masih terakuinya lahan hutan ulayat sebagai lahan milik komunitas Binua, luasan lahan ulayat masih memungkinkan untuk digunakan oleh penduduk untuk kegiatan perladangan padi dengan rotasi penggunaan lahan perladangan dengan masa bera 10 - 15 tahun (Benyamine, 2009).

Binua atau kampong sebagai Self governing community hancur semenjak pemberlakuan UU Nomor 5 Tahun 1979, dimana binua-binua atau kampongkampong digabungkan menjadi desa administratif. Tanah hutan ulayat yang sejak ratusan tahun lalu menjadi milik komunitas binua diklaim sebagai tanah negara, dan hak komunitas binua untuk memiliki dan mengelola sumberdaya alam di sekitarnya menjadi hilang. Tanah hutan ulayat kemudian diserahkan pengelolaannya pada para pemegang $\mathrm{HPH}$, sehingga dengan demikian luasan lahan hutan yang biasa dijadikan kawasan perladangan berpindah menjadi jauh menyempit. Akibatnya, rotasi masa bera antara satu lahan dengan lahan lainnya yang biasa digunakan oleh masyarakat menjadi semakin singkat, yaitu berkisar antara 3-5 tahun (Edi Petebang, 1999).
Jumlah luasan perladangan padi di Kalimantan Barat menurut data BPS (2010) adalah $105.405 \mathrm{Ha}$, dan menurut penelitian Ikhrosnaeni (2006), rerata lahan perladangan padi yang diusahakan per KK oleh masyarakat desa Hutan di Kalimantan Barat dalam kegiatan ladang berpindah adalah seluas 1,12 $\mathrm{Ha}$. Ini artinya, di Kalimantan Barat setidaknya ada sekitar 94.112 KK petani padi yang menggandalkan sumber makanan pokok keluarga mereka dari kegiatan ladang berpindah.

Terdapatnya dua kondisi yang saling kontra produktif, yang dihadapi khususnya oleh petani peladang berpindah di Kalimantan Barat, yaitu makin menyempitnya luasan lahan yang bisa digunakan untuk kegiatan perladangan padi sebagai sumber makanan pokok di satu sisi, dan kondisi semakin meningkatnya pertumbuhan penduduk di sisi lain, merupakan dua kondisi ancaman bagi ketahanan pangan pokok keluarga mereka. Ketahanan pangan pokok keluarga, (sejalan dengan pengertian menurut PP Nomor 28 tahun 2002 tentang ketahanan pangan), dalam hal ini diartikan sebagai "Kondisi terpenuhinya pangan pokok (beras) bagi rumah tangga petani, yang tercermin dari tersedianya pangan pokok yang cukup dalam hal jumlah dan mutunya". Keterancaman ketahanan pangan pokok mereka akan semakin meningkat di masa mendatang, jika ternyata kondisi-kondisi yang berkaitan dengan peladang berpindah, tiada kunjung mengalami perubahan ke arah lebih baik dari kondisi saat ini.

Memperhatikan besarnya jumlah desa hutan dan jumlah penduduknya yang berstatus sebagai peladang berpindah ternyata relatif cukup banyak di Indonesia, dimana jumlah dari mereka juga banyak terkategorikan sebagi penduduk miskin di satu sisi, maka salah satu alternatif untuk menanggulanginya adalah melalui "program pembinaan intensif pada keluarga petani peladang berpindah", dalam bentuk program transformasi pola perladangan berpindah ke program pembinaan pola usahatani lahan menetap".

Walaupun sifatnya bukanlah sebagai program yang ditujukan khusus untuk mentransformasikan kegiatan perladangan berpindah menjadi pola perladangan menetap, namun salah satu bentuk program pemerintah yang mengarah pada upaya transformasi dari keluarga petani di Kalimantan Barat, yang awalnya menerapkan pola perladangan berpindah menjadi petani pola ladang menetap adalah "Program Transmigrasi Penduduk Setempat (TPS)", yang merupakan bagian dari Program Transmigrasi Umum (PTU). Pada Program Transmigrasi Umum ini, petani peserta program bukan melulu berasal dari luar propinsi, namun juga memasukkan peserta transmigrasi yang berasal dari penduduk lokal. Khususnya di Kalimantan Barat, penduduk setempat yang dimaksudkan tersebut diantaranya adalah para penduduk suku dayak dan suku melayu pedalaman yang awalnya berprofesi sebagai petani peladang berpindah. Salah satu lokasi transmigrasi umum yang diselenggarakan di Kalimantan Barat adalah di lokasi permukiman transmigrasi Sabung SP 1 yang berada di wilayah administrasi Kabupaten Sambas.

Salah satu tujuan yang ingin dicapai dari diselenggarakannya program transmigrasi adalah upaya peningkatan kesejahteraan petani transmigran, baik kesejahteraan secara objektif (Kesejahteraan materiil yang diukur secara objektif antara lain berdasarkan tingkat pendapatan), maupun kesejahteraan Non materil (yang diukur secara subjektif 
antara lain berdasarkan tingkat kepuasan terhadap halhal non pangan para transmigran), antara lain kepuasan para transmigran terhadap kondisi fasilitas rumah dan lahan, fasilitas pendidikan, fasilitas kesehatan, fasilitas penerangan, fasilitas prasarana transportasi dan kondisi ketentraman dalam interaksi sosial).

Berdasarkan tujuan program transmigrasi tersebut, maka adalah penting untuk meneliti sejauhmana dampak perubahan pola usahatani para transmigran lokal dari pola usahatani perladangan menjadi pola usahatani pertanian menetap di lokasi transmigrasi, terhadap perubahan tingkat kesejahteraan mereka antara sebelum mengikuti dan setelah mengikuti program transmigrasi.

Tingkat Kesejahteraan seseorang atau sekelompok masyarakat dapat diukur menurut kategori yang berkaitan dengan konsep tingkat kemiskinan. Menurut Lokshin dan Ravallion dalam Suandi dan Damayanti (2010), pengertian kesejahteraan dilihat dari dua pendekatan, yakni: "kesejahteraan Objektif" dan "kesejahteraan Subjektif". Kesejahteraan objektif adalah tingkat kesejahteraan individu atau kelompok masyarakat yang diukur secara rata-rata dengan patokan tertentu, baik ukuran ekonomi, sosial maupun ukuran lainnya, Dengan kata lain, tingkat kesejahteraan seorang individu atau kelompok masyarakat diukur dengan pendekatan yang baku. Salah satu ukuran kesejahteraan secara objektif antara lain yaitu diukur menurut kategori tingkat kemiskinan yang dikemukakan oleh Zulkifli Husin dalam Supriatna (1997), yaitu bisa dilakukan dengan menggunakan Rasio Kebutuhan Fisik Minimum sesuai dengan kondisi yang dihadapi saat ini, maka jika diumpamakan untuk memenuhi kebutuhan hidup empat sehat lima sempurna per kapita per hari adalah Rp. 2.500, maka dapat ditentukan nilai kebutuhan fisik minimum per tahun yaitu sebesar Rp. 2.500 x 365 hari = Rp. 912.500. Apabila nilai kebutuhan fisik minimum per kapita per tahun ini dijadikan sebagai pembagi, maka akan diperoleh Rasio Kebutuhan Fisik Minimum (R-KFM). Dari hasil perhitungan tersebut dapat dikategorikan apakah penduduk tersebut miskin atau tidak. Jika nilai R-KFM yang diperoleh sama dengan satu, berarti penduduk tersebut dikategorikan sebagai penduduk miskin, karena tingkat pendapatannya setingkat dengan tingkat subsisten (subsistance level). Artinya, pendapatan yang diperoleh orang tersebut hanya cukup untuk mempertahankan hidup. Formulasi pengkategorian tingkat kemiskinan berdasar R-KFM adalah :

a. R-KFM $\leq 0,75 \rightarrow$ Miskin sekali

b. R-KFM 0,76-1,00 $\rightarrow$ Miskin

c. R-KFM 1,01-1,50 $\rightarrow$ Nyaris Miskin

d. R-KFM 1,51-2,00 $\rightarrow$ Nyaris Kaya

Adapun kesejahteraan subjektif, adalah tingkat kesejahteraan seorang individu yang dilihat secara personal, dan diukur dalam bentuk kepuasan dan kebahagiaan. Menurut hasil penelitian Sumarti (1999) dalam Suandi dan Damayanti (2010), kesejahteraan subjektif individu atau keluarga adalah wujud kebudayaan yang dihasilkan melalui proses pengalaman hidup sekelompok manusia dalam hubungannya dengan lingkungan (fisik dan sosial). Artinya, pengertian kesejahteraan haruslah berpedoman pada subjektivitas masyarakat setempat (lokal). Menurut Angel, dan Black Well, dan Miniard (Sumarwan, 2003), kesejahteraan subjektif diukur dalam bentuk kepuasan, dimana "satisfaction is defined here as past consumption evaluation that a chosesn alternative at least meets or exeeds expectation" (kepuasan merupakan hasil evaluasi dari konsumsi yang lalu sehingga alternatif yang dipilih paling tidak sesuai dengan kriteria atau melebihi krteria yang diharapkan).

Pengukuran kesejahteraan secara subjektif, antara lain dilakukan berdasar tolak ukur kepuasan terhadap : (1) Pemenuhan kebutuhan pangan, (2) Pemenuhan kebutuhan Non Pangan, dan (3) Pemenuhan investasi Sumberdaya manusia.

Kepuasan pemenuhan kebutuhan non pangan, diukur dari kepuasan pemenuhan akan sandang/ pakaian, papan/perumahan, energi, prasarana dan sarana komunikasi/transportasi, serta pemenuhan kebutuhan sosial/kemasyarakatan. Sedangkan kepuasan terhadap pemenuhan kebutuhan investasi SDM keluarga, dapat diukur dari kepuasan terhadap pemenuhan kebutuhan akan biaya pendidikan dan biaya kesehatan. (Suandi dan Damayanti, 2010). Kebutuhan sosial/kemasyarakatan menurut Sudjarwo (1997) antara lain berkaitan dengan tingkat keharmonisan interaksi sosial antara individu satu dengan individu lain, individu dengan kelompok atau kelompok satu dengan kelompok lainnya. Tingkat keharmonisan interaksi sosial ini terlihat dari rentang jarak sosial yang terjadi di masyarakat, dimana rentang sosial ini akan dipengaruhi oleh sikap yang terjadi antara satu komponen mansyarakat satu dengan komponen masyarakat lainnya.

Keberhasilan upaya peningkatan kesejahteraan materil para petani dapat diukur melalui tingkat pendapatan yang bisa dicapai oleh para petani tersebut. Tingkat pendapatan petani akan ditentukan terutama dari sejauhmana keberhasilan pembangunan pertanian dapat tercapai di wilayah mereka. Menurut teori klasik yang dikemukakan oleh Mosher A.T (1966), pembangunan pertanian di suatu wilayah akan ditentukan oleh sejauh mana ketersediaan faktor mutlak dan faktor pelancar usahatani. Faktor mutlak mencakup : Adanya inovasi teknologi usahatani yang terus menerus, ketersediaan sarana produksi saat diperlukan petani, tersedianya pasar hasil usahatani, adanya harga produksi yang menguntungkan petani, tersedianya sarana dan prasarana pengangkutan. Adapun faktor pelancar diantaranya adalah : Adanya pendidikan inovasi teknologi bagi petani (melalui penyuluhan), ketersediaan kredit usahatani, serta adanya perbaikan kondisi lahan usahatani. Selain hal di atas, menurut Sai'd (2001), faktor input tenaga kerja merupakan hal penting dalam proses produksi usahatani.

Tujuan akhir yang ingin dicapai dari pelaksanaan program transmigrasi adalah peningkatan kualitas kesejahteraan para transmigran, terutama transmigran yang berasal dari penduduk setempat/lokal. Kesejahteraan yang dimaksudkan yaitu mencakup kesejahteraan materil dan non materil.

Kesejahteraan materil petani transmigran sangat ditentukan oleh kondisi tinggi-rendahnya pendapatan dari hasil usahatani mereka, pada lahan usahatani dan lahan pekarangan yang disediakan oleh pemerintah di lokasi transmigrasi. Faktor utama yang menjadi penentu keberhasilan petani dalam usahatani mereka adalah tingkat adopsi inovasi oleh petani itu sendiri. Tingkat adopsi ini dipengaruhi oleh kondisi variabelvariabel : (1) Kualitas serapan inovasi dari penyuluh ; (2) Kualitas serapan inovasi teknologi dari petani lain; (3) Potensi TK dan Modal Keluarga; (4) Ketersediaan saprodi, kredit usahatani, dan pasar hasil usahatani. Tinggi rendahnya tingkat adopsi inovasi teknologi oleh petani ini akan menentukan tingkat produksi yang 
mereka capai, dan ini berkorelasi terhadap tingkat pendapatan mereka.

Kesejahteraan Non materil petani transmigran dipengaruhi oleh dua kondisi utama, yaitu aspek kepuasan terhadap prasarana dan sarana yang bisa mereka peroleh di lokasi transmigrasi, serta aspek keharmonisan interaksi sosial yang tercipta diantara sesama petani dalam kehidupan keseharian. Khususnya berkaitan dengan aspek interaksi sosial antar petani transmigran setempat dan transmigran pendatang, kondisinya akan dapat diukur dari sejauhmana jarak sosial yang terjadi diantara mereka. Renggang atau tidaknya jarak sosial yang terjadi diantara mereka tergantung pada faktor sikap petani/kelompok petani satu terhadap petani/ kelompok petani lainnya. Terbentuknya jenis sikap ini sangat dipengaruhi oleh latar belakang budaya petani/kelompok petani bersangkutan. Secara visual jalinan antar variabel ini terlihat dari paradigma penelitian pada Gambar 1.

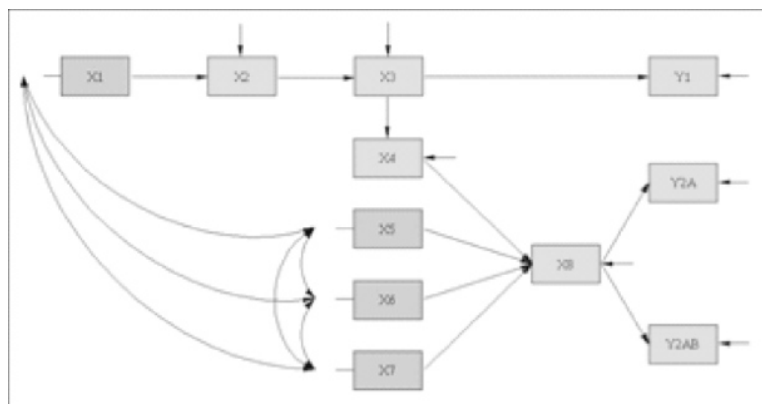

Gambar 1. Diagram Konseptual Hubungan Struktural Antar Variabel

Keterangan :

$\mathrm{X}_{1}=$ Sikap Terhadap Etnis Lain

$\mathrm{X}_{2}=$ Rentang Jarak Sosial.

$X_{3}=$ Keharmonisan Interaksi Sosial.

$X_{4}=$ Serapan Inovasi dari Sesama Petani.

$\mathrm{X}_{5}=$ Sikap Petani terhadap Kegiatan Penyuluhan

$X_{6}=$ Kondisi Internal Petani.

$\mathrm{X}_{7}=$ Ketersediaan Lembaga Pendukung Usahatani.

$\mathrm{X}_{8}=$ Tingkat Adopsi Inovasi teknologi usahatani.

$\mathrm{Y}_{1}=$ Tingkat Kepuasan Petani terhadap Kondisi Fasilitas dan Lingkungan Sosial.

$\mathrm{Y} 2_{\mathrm{A}}=$ Pendapatan dari Usahatani Milik Sendiri.

$\mathrm{Y} 2 \mathrm{AB}=$ Tingkat Pendapatan.

\section{Hipotesis}

Berdasar pada tinjauan pustaka dan proposisiproposisi yang diuraikan pada kerangka pikir di atas, maka beberapa proposisi sebagai hipotesis yang perlu diuji kebenarannya dalam penelitian ini adalah:

$\mathrm{H} 1=$ Sikap petani transmigran lokal terhadap petani transmigran pendatang berpengaruh terhadap rentang jarak sosial diantara mereka.

$\mathrm{H} 2=$ Rentang jarak sosial antara petani transmigran lokal dengan petani transmigran pendatang akan berpengaruh terhadap tingkat keharmonisan interaksi sosial mereka.

H3 = Tingkat keharmonisan interaksi sosial antara petani transmigran lokal dengan petani transmigran pendatang akan berpengaruh terhadap tingkat kesejahteraan non materil Transmigran lokal.

$\mathrm{H} 4=$ Tingkat keharmonisan interaksi sosial antara petani transmigran lokal dengan petani transmigran pendatang akan berpengaruh terhadap tingkat serapan inovasi teknologi petani transmigran lokal dari petani transmigran pendatang.
H5 = Tingkat serapan inovasi/pengetahuan tentang inovasi dari petani pendatang, tingkat serapan inovasi dari penyuluh, ketersediaan lembaga pendukung usahatani dan Potensi internal usahatani keluarga (potensi TK dan modal dan luas lahan) akan berpengaruh terhadap tingkat penerapan /adopsi inovasi oleh petani lokal.

H6 = Tingkat Penerapan/ adopsi inovasi mempengaruhi tingkat pendapatan usahatani petani transmigran lokal/ tingkat kesejahteraan materil petani dari usahatani di lokasi transmigrasi.

H7 = Tingkat Penerapan/adopsi inovasi mempengaruhi tingkat pendapatan total petani transmigran lokal.

\section{Metode}

Objek utama penelitian adalah petani peladang berpindah yang mengikuti program transmigrasi umum di wilayah transmigrasi umum Sabung SP 1 di kabupaten Sambas Propinsi Kalimantan Barat. Pemilihan lokasi dilakukan secara purposive dengan pertimbangan lokasi transmigrasi umum tersebut baru berjalan sekitar 4 tahun, berarti masih dalam masa pembinaan penuh dari pihak Departemen Tenaga Kerja dan Transmigrasi.

Metode yang digunakan dalam penelitian ini adalah metode survei. Menurut Singarimbun dan Effendi (1987), penelitian survei adalah penelitian yang mengambil sampel dari populasi dengan menggunakan kuesioner sebagai alat bantu pengumpulan data.

Penelitian ini bersifat deskriptif eksplanatoris. Deskriptif bertujuan untuk memperoleh gambaran secara sistematis, faktual dan akurat mengenai faktafakta, sifat-sifat serta hubungan dari variabel yang diteliti. Eksplanatoris bertujuan untuk mengetahui hubungan kausal antar variabel dalam hipotesis. (Kuswantinah, 2005). Indept study melalui observasi langsung, observasi partisipasi dan wawancara bebas, juga dilakukan dalam penelitian ini untuk memperdalam pemahaman atas permasalahan yang diteliti, guna membahas fenomena yang sulit didekati secara kuantitatif.

Jumlah seluruh populasi petani transmigran lokal adalah 125 KK. Penentuan ukuran sampel petani dilakukan dengan menggunakan rumus ukuran sampel inimum dari Slovin dalam Paturochman (2012) sebagai berikut:

$$
\mathrm{n}=\frac{\mathrm{N}}{\mathrm{Ne}^{2}+1}
$$

Dimana :

$\mathrm{n}$ = Ukuran sampel petani

$\mathrm{N}=$ Ukuran Populasi petani.

e = Presisi yang diinginkan (95\%) /tingkat kesalahan yang ditolerir (5\%)

1 = Angka konstanta.

Berdasarkan rumus ukuran sampel minimal di atas, maka ukuran sampel minimal dalam penelitian ini adalah:

$$
n=\frac{125}{125(0,05)^{2}+1}=77 K K
$$

Pengambilan data dilakukan dengan alat bantu kuesioner, menggunakan skala Likert dengan hasil data mentah berupa data ordinal. Metode analisis data yang 
digunakan adalah analisis jalur (Path Analysis), menggunakan program LISREL. Analisis jalur merupakan bagian dari statistika parametrik yang digunakan untuk menganalisis data interval atau rasio (Sugiyono, 2007) yang mengasumsikan adanya distribusi normal. Untuk keperluan tersebut, maka data yang berskala ordinal ditransformasikan terlebi dahulu ke dalam skala interval melalui Method of successive interval (MSI). Untuk melihat tingkat signifikansi perbedaan tingkat pendapatan petani lokal dari usahatani antara sebelum dan sesudah mengikuti program transmigrasi digunakan Uji beda Wilcoxon.

Hasil dan Pembahasan

A) Pengaruh Sikap Petani Lokal Terhadap Rentang Jarak Sosial dengan Petani Transmigran Pendatang.

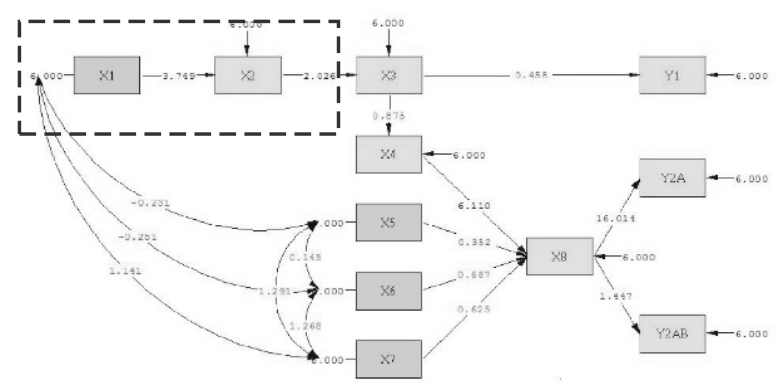

Gambar 2. Diagram Nilai t Pengaruh X1 Terhadap X2

Berdasarkan hasil estimasi yang disajikan melalui gambar diagram di atas diketahui bahwa nilai thitung pengaruh X1 terhadap X2 adalah sebesar 3,749. Dengan taraf signifikansi $(\alpha)$ sebesar 0,05 dan derajat bebas sebesar $n-k-1=77-1-1=75$ didapat nilai ttabel dari tabel distribusi $t$ dua pihak sebesar 1,992. Dikarenakan nilai mutlak thitung lebih besar dari nilai ttabel $(|3,749|>1,992)$, maka dapat disimpulkan bahwa secara statistik, pengaruh $\mathrm{X} 1$ terhadap $\mathrm{X} 2$ tersebut signifikan.

Berdasar hasil uji statistik di atas maka dapat dideskripsikan hal-hal sebagai berikut:

1. Perubahan yang terjadi pada sikap petani transmigran lokal terhadap petani transmigran pendatang berpengaruh secara nyata terhadap perubahan jarak sosial diantara mereka (Tolak $\mathrm{H}_{0}$ dan Terima $\mathrm{H}_{1}$ ).

2. Perubahan yang terjadi pada sikap petani transmigran lokal terhadap petani transmigran pendatang akan berbanding lurus dengan perubahan rentang jarak sosial diantara mereka. Artinya, semakin positif sikap petani transmigran lokal terhadap transmigran pendatang maka rentang jarak sosial diantara mereka akan semakin kecil, dan sebaliknya.

3. Sikap petani transmigran lokal terhadap transmigran pendatang hanya mempengaruhi besar kecilnya rentang jarak sosial diantara mereka sebesar $16,33 \%$ saja. Jauh dekatnya/besar-kecilnya jarak sosial antara petani transmigran lokal dengan transmigran pendatang $83,67 \%$ ditentukan oleh varibel-variabel lain selain sikap petani transmigran lokal terhadap petani transmigran pendatang.

B) Pengaruh Rentang Jarak Sosial Terhadap Keharmonisan Interaksi antara Petani Transmigran Lokal dengan Transmigran Pendatang.

Berdasarkan hasil estimasi yang disajikan melalui gambar 3, diketahui bahwa nilai thitung pengaruh $\mathrm{X} 2$ terhadap $X 3$ adalah sebesar 2,026. Dengan taraf signifikansi $(\alpha)$ sebesar 0,05 dan derajat bebas sebesar n-k-1 = 77-1-1 = 75 didapat nilai tabel dari tabel distribusi t dua pihak sebesar 1,992. Dikarenakan nilai mutlak thitung lebih besar dari nilai tabel $(|2,026|>1,992)$, maka dapat disimpulkan bahwa secara statistik, pengaruh X2 terhadap X3 tersebut signifikan.

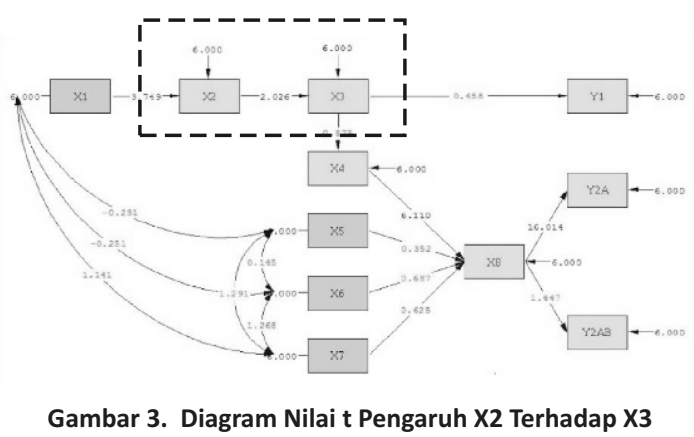

Hasil uji statistik di atas khususnya berkaitan dengan Hipotesis kedua, dimana berdasar hasil uji statistik di atas maka dapat dideskripsikan hal-hal sebagai berikut :

1. Perubahan yang terjadi pada Rentang jarak sosial antara petani transmigran lokal dengan petani transmigran pendatang berpengaruh secara nyata terhadap perubahan tingkat keharmonisan sosial diantara mereka (Tolak $\mathrm{H}_{0}$ dan Terima $\mathrm{H}_{1}$ ).

2. Perubahan yang terjadi pada Rentang jarak sosial antara transmigran lokal dengan petani transmigran pendatang akan berbanding lurus dengan perubahan tingkat keharmonisan interaksi sosial diantara mereka. Artinya, semakin positif rentang jarak sosial transmigran lokal dengan transmigran pendatang maka tingkat keharmonisan interaksi sosial diantara mereka akan semakin positif, dan sebaliknya.

3. Rentang jarak sosial antara transmigran lokal dengan transmigran pendatang hanya mempengaruhi tingkat keharmonisan interaksi sosial diantara mereka sebesar 5,39\%, sedangkan sisanya sebesar 94,61\% tingkat keharmonisan interaksi sosial diantara mereka tersebut ditentukan oleh kontribusi variabel lain yang tidak diamati di dalam penelitian ini.

C) Pengaruh Tingkat Keharmonisan Interaksi Sosial antara Petani Transmigran Lokal dengan Transmigran Pendatang terhadap Kesejahteraan Non Materil Petani Transmigran Lokal.

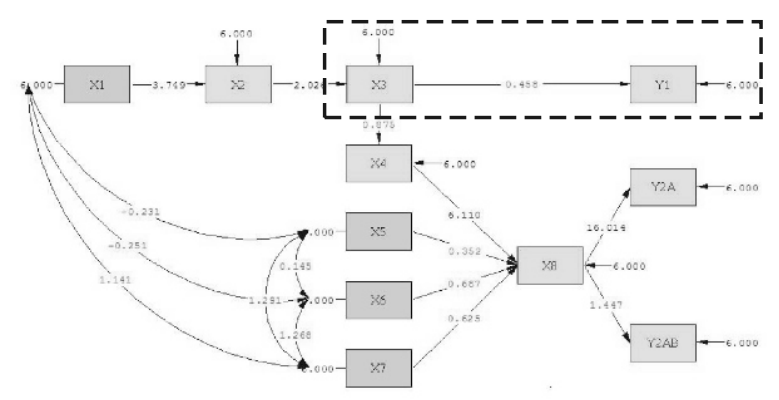

Gambar 4. Diagram Nilai t Pengaruh X3 Terhadap Y1

Berdasarkan hasil estimasi yang disajikan melalui gambar diagram di atas diketahui bahwa nilai thitung pengaruh X3 terhadap Y1 adalah sebesar 0,458. 
Dengan taraf signifikansi $(\alpha)$ sebesar 0,05 dan derajat bebas sebesar $n-k-1=77-1-1=75$ didapat nilai tabel dari tabel distribusi t dua pihak sebesar 1,992. Dikarenakan nilai mutlak thitung lebih kecil dari nilai tabel $(|0,458|<$ 1,992), maka dapat disimpulkan bahwa secara statistik, pengaruh X3 terhadap Y1 tersebut tidak signifikan.

Hasil uji statistik di atas khususnya berkaitan dengan Hipotesis ketiga, dimana berdasar hasil uji statistik di atas maka dapat dideskripsikan hal-hal sebagai berikut :

1. Perubahan yang terjadi pada tingkat keharmonisan interaksi sosial antara petani transmigran lokal dengan petani transmigran pendatang tidak berpengaruh secara nyata terhadap perubahan tingkat kesejahteraan Non mateil petani transmigran lokal (Terima $\mathrm{H}_{0}$ dan Tolak $\mathrm{H}_{1}$ ).

2. Perubahan yang terjadi pada tingkat keharmonisan interaksi sosial antara transmigran lokal dengan petani transmigran pendatang berbanding lurus dengan perubahan tingkat kesejahteraan Non materil petani transmigran lokal. Artinya, semakin positif tingkat keharmonisan interaksi sosial transmigran lokal maka tingkat kesejahteraan Non mateil petani transmigran lokal juga akan semakin positif, dan sebaliknya.

3. Tingkat Keharmonisan interaksi sosial antara transmigran lokal dengan transmigran pendatang hanya mempengaruhi tingkat tingkat kesejahteraan non materil petani transmigran lokal sangat kecil sekali yaitu hanya sebesar 0,29\%, sedangkan sisanya sebesar 99,71\% tingkat kesejahteraan Non materil petani transmigran lokal tersebut ditentukan oleh kontribusi variabel lain yang tidak diamati di dalam penelitian ini.

D) Pengaruh Tingkat Keharmonisan interaksi sosial terhadap tingkat serapan inovasi teknologi petani transmigran lokal dari petani transmigran pendatang.

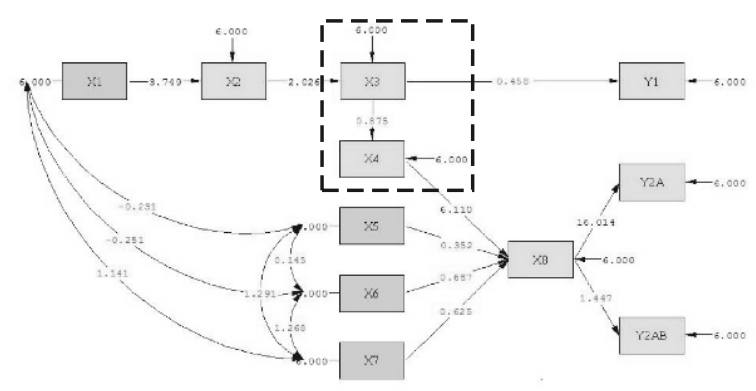

Gambar 5. Diagram Nilai t Pengaruh X3 Terhadap X4

Berdasarkan hasil estimasi yang disajikan melalui gambar diagram di atas diketahui bahwa nilai thitung pengaruh X3 terhadap X4 adalah sebesar 0,875. Dengan taraf signifikansi $(\alpha)$ sebesar 0,05 dan derajat bebas sebesar $n-k-1=77-1-1=75$ didapat nilai tabel dari tabel distribusi t dua pihak sebesar 1,992. Dikarenakan nilai mutlak thitung lebih kecil dari nilai tabel $(|0,875|<$ 1,992), maka dapat disimpulkan bahwa secara statistik, pengaruh X3 terhadap X4 tersebut tidak signifikan.

Hasil uji statistik di atas khususnya berkaitan dengan Hipotesis keempat, dimana berdasar hasil uji statistik di atas maka dapat dideskripsikan hal-hal sebagai berikut:

1. Perubahan yang terjadi pada Tingkat Keharmonisan interaksi sosial antara petani transmigran lokal dengan petani transmigran pendatang ber- pengaruh secara nyata terhadap perubahan tingkat serapan inovasi teknologi petani transmigran lokal dari petani transmigran pendatang (Tolak $\mathrm{H}_{0}$ dan Terima $\mathrm{H}_{1}$ ).

2. Perubahan yang terjadi pada Tingkat Keharmonisan interaksi sosial antara transmigran lokal dengan petani transmigran pendatang berbanding lurus dengan perubahan tingkat serapan inovasi teknologi petani transmigran lokal dari petani transmigran pendatang. Artinya, semakin positif Tingkat Keharmonisan interaksi sosial antara transmigran lokal dengan petani transmigran pendatang maka tingkat serapan inovasi teknologi petani transmigran lokal dari petani transmigran pendatang akan semakin positif, dan sebaliknya.

3. Tingkat Keharmonisan interaksi sosial antara transmigran lokal dengan petani transmigran pendatang hanya mempengaruhi tingkat serapan inovasi teknologi petani transmigran lokal dari petani transmigran pendatang sebesar 1,05\%, sedangkan sisanya sebesar $98,95 \%$ tingkat serapan inovasi teknologi petani transmigran lokal dari petani transmigran pendatang tersebut ditentukan oleh kontribusi variabel lain yang tidak diamati di dalam penelitian ini.

E) Pengaruh variabel Serapan inovasi dari sesama petani,sikap petani terhadap kegiatan penyuluhan, kondisi internal petani dan ketersediaan lembaga pendukung usahatani di lokasi transmigrasi terhadap Adopsi inovasi teknologi usahatani oleh Petani Lokal.

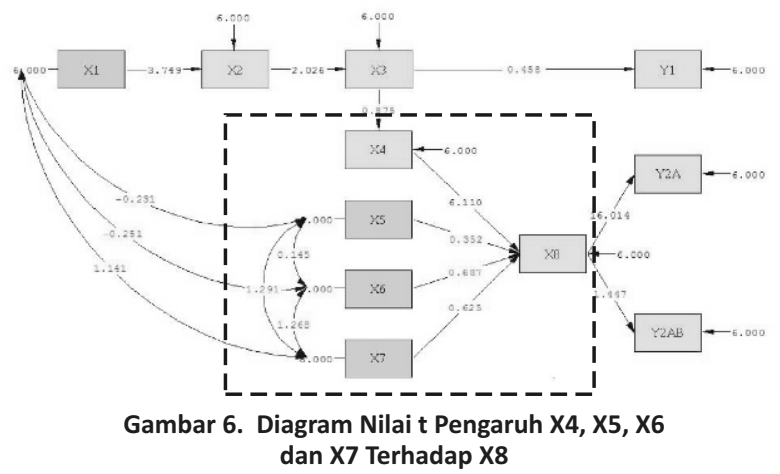

Berdasarkan hasil estimasi yang disajikan melalui gambar diagram di atas diketahui bahwa nilai thitung pengaruh X4 terhadap X8 adalah sebesar 6,110, nilai thitung pengaruh X5 terhadap X8 adalah sebesar 0,352 , nilai thitung pengaruh $\mathrm{X} 6$ terhadap $\mathrm{X} 8$ adalah sebesar 0,687 dan nilai thitung pengaruh $X 7$ terhadap $X 8$ adalah sebesar 0,625. Dengan taraf signifikansi $(\alpha)$ sebesar 0,05 dan derajat bebas sebesar $n-k-1=77-4-1=71$ didapat nilai tabel dari tabel distribusi $t$ dua pihak sebesar 1,994. Dikarenakan nilai mutlak thitung pengaruh X4 terhadap X8 lebih besar dari nilai tabel $(|6,110|>$ 1,994), maka dapat disimpulkan bahwa secara statistik, pengaruh X4 terhadap X8 tersebut signifikan. Dikarenakan nilai mutlak thitung pengaruh X5 terhadap X8 lebih kecil dari nilai tabel $(|0,352|<1,994)$, maka dapat disimpulkan bahwa secara statistik, pengaruh X5 terhadap X8 tersebut tidak signifikan. Dikarenakan nilai mutlak thitung pengaruh $\mathrm{X} 6$ terhadap $\mathrm{X} 8$ lebih kecil dari nilai tabel $(|0,687|<1,994)$, maka dapat disimpulkan bahwa secara statistik, pengaruh $\mathrm{X} 6$ terhadap $\mathrm{X} 8$ tersebut tidak signifikan. Dikarenakan nilai mutlak thitung 
pengaruh $\mathrm{X} 7$ terhadap $\mathrm{X} 8$ lebih kecil dari nilai tabel $(|0,625|<1,994)$, maka dapat disimpulkan bahwa secara statistik, pengaruh $\mathrm{X} 7$ terhadap $\mathrm{X} 8$ tersebut tidak signifikan.

Berdasar hasil uji statistik di atas, dimana hasil tersebut berkaitan dengan Hipotesis kelima, dapat dijelaskan Dua hal sebagai berikut:

1. Serapan inovasi dari sesama petani berpengaruh secara nyata terhadap tingkat adopsi inovasi oleh petani transmigran lokal. Ada pun variabel sikap petani terhadap kegiatan penyuluhan, kondisi internal petani dan ketersediaan lembaga pendukung usahatani di lokasi transmigrasi Sabung SP 1 secara masing-masing (parsial), tidak berpengaruh secara nyata terhadap adopsi inovasi oleh transmigran lokal.

2. Secara simultan, tingkat adopsi inovasi petani transmigran lokal sebesar $34,7 \%$, ditentukan oleh varibel Serapan inovasi dari sesama petani, sikap petani terhadap kegiatan penyuluhan, kondisi internal petani dan ketersediaan lembaga pendukung usahatani di lokasi transmigrasi Sabung SP 1,sedangkan sisanya sebesar 65,3\% merupakan kontribusi variabel lain yang tidak diamati di dalam sub struktur 5 model analisis jalur penelitian ini.

Tabel 2. Koefisien Determinasi Variabel X4, X5, X6 dan X7 Secara Simultan Terhadap $\mathbf{X 8}$

Squared Multiple Correlations for Structural Equations \begin{tabular}{lccccc}
$\mathrm{X} 2$ & $\mathrm{X} 3$ & $\mathrm{X} 4$ & $\mathrm{X} 8$ & $\mathrm{Y} 1$ & $\mathrm{Y} 2 \mathrm{~A}$ \\
\hdashline 0.163 & 0.054 & 0.011 & 0.347 & 0.003 & 0.781
\end{tabular}

F) Pengaruh Tingkat Adopsi Teknologi Usahatani terhadap Tingkat Pendapatan Petani Transmigran Lokal dari Usahatani.

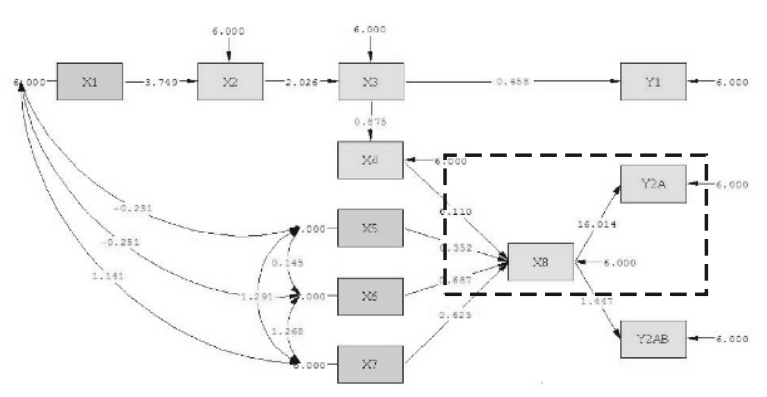

Gambar 7. Diagram Nilai t Pengaruh X8 Terhadap Y2A

Berdasarkan hasil estimasi yang disajikan melalui gambar diagram di atas diketahui bahwa nilai thitung pengaruh X8 terhadap Y2A adalah sebesar 16,014. Dengan taraf signifikansi $(\alpha)$ sebesar 0,05 dan derajat bebas sebesar n-k-1 = 77-1-1 = 75 didapat nilai tabel dari tabel distribusi t dua pihak sebesar 1,992. Dikarenakan nilai mutlak thitung lebih besar dari nilai tabel $(|16,014|$ $>$ 1,992), maka dapat disimpulkan bahwa secara statistik, pengaruh X8 terhadap Y2A tersebut signifikan.

Hasil uji statistik di atas khususnya berkaitan dengan Hipotesis keenam, dimana berdasar hasil uji statistik di atas maka dapat dideskripsikan hal-hal sebagai berikut:

1. Perubahan yang terjadi pada Tingkat adopsi inovasi petani transmigran lokal berpengaruh secara nyata terhadap perubahan tingkat pendapatan usahatani mereka (Tolak $\mathrm{H}_{0}$ dan Terima $\mathrm{H}_{1}$ ).

2. Perubahan yang terjadi pada Tingkat adopsi inovasi petani transmigran lokal berbanding lurus dengan perubahan tingkat pendapatan dari usahatani mereka.

3. Tingkat adopsi inovasi transmigran lokal menentukan tingkat tingkat pendapatan usahatani petani transmigran lokal sebesar $78,15 \%$, sedangkan sisanya sebesar $21,85 \%$ merupakan kontribusi variabel lain yang tidak diamati di dalam sub struktur 7 model analisis jalur penelitian ini.

G) Pengaruh Tingkat Adopsi Teknologi Usahatani terhadap Pendapatan Total Petani Transmigran Lokal.

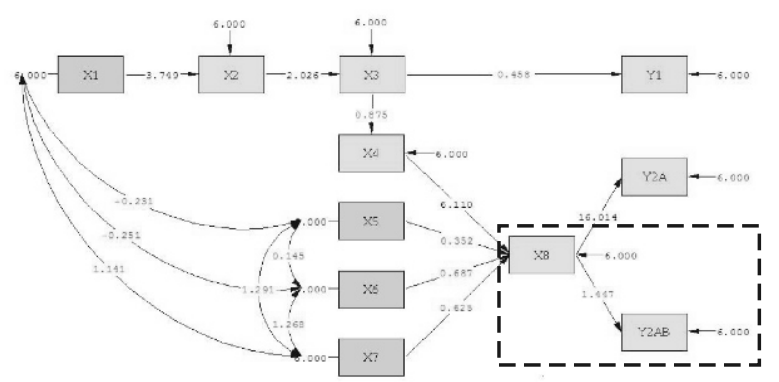

Gambar 8. Diagram Nilai t Pengaruh X8 Terhadap Y2AB

Berdasarkan hasil estimasi yang disajikan melalui gambar diagram di atas diketahui bahwa nilai thitung pengaruh X8 terhadap Y2AB adalah sebesar 1,447. Dengan taraf signifikansi $(\alpha)$ sebesar 0,05 dan derajat bebas sebesar $n-k-1=77-1-1=75$ didapat nilai tabel dari tabel distribusi t dua pihak sebesar 1,992. Dikarenakan nilai mutlak thitung lebih kecil dari nilai tabel $(|1,447|<$ 1,992), maka dapat disimpulkan bahwa secara statistik, pengaruh X8 terhadap Y $2 A B$ tersebut tidak signifikan.

Hasil uji statistik di atas khususnya berkaitan dengan Hipotesis ketujuh, dimana berdasar hasil uji statistik di atas maka dapat dijelaskan hal-hal sebagai berikut:

1. Perubahan yang terjadi pada Tingkat adopsi inovasi petani transmigran lokal tidak berpengaruh secara nyata terhadap perubahan tingkat pendapatan total mereka (Terima $\mathrm{H}_{0}$ dan Tolak $\mathrm{H}_{1}$ ). Hal ini dimungkinkan karena saat ini pendapatan total petani transmigran lokal lebih banyak bersumber dari non usahatani dibanding dari hasil usahatani mereka di lokasi transmigrasi. Hal ini terlihat dari kenyataan bahwa Tingkat adopsi inovasi transmigran lokal hanya menentukan tingkat pendapatan usahatani petani transmigran lokal sebesar 2,82\%, sedangkan sisanya sebesar $97,18 \%$ merupakan kontribusi variabel lain, yang dalam hal ini variabel penentu tersebut kemungkinan besar adalah ditentukan oleh pendapatan mereka di luar usahatani atau non usahatani di luar lokasi transmigrasi.

2. Perubahan yang terjadi pada Tingkat adopsi inovasi petani transmigran lokal berbanding lurus dengan perubahan tingkat pendapatan dari usahatani mereka. Artinya, walaupun peran adopsi inovasi petani transmigran lokal sedikit pengaruhnya terhadap besar kecilnya pendapatan total mereka, namun kenaikan pendapatan dari usahatani akan turut meningkatkan pendapatan total mereka, dan sebaliknya. 
Untuk mengetahui signifikansi pendapatan usahatani petani transmigran lokal antara sebelum dan sesudah mengikuti program transmigran, dilakukan dengan Uji beda menggunakan Test Wilcoxon, dimana ternyata terdapat perbedaan yang signifikan antara pendapatan usahatani sebelum mengikuti program transmigrasi dan setelah mengikuti program transmigrasi.

\section{Simpulan}

Pertama : Sikap petani transmigran lokal terhadap transmigran pendatang berpengaruh nyata pada rentang jarak sosial mereka. Semakin positif sikap petani transmigran lokal terhadap transmigran pendatang, maka semakin positif/semakin kecil rentang jarak sosial antara transmigran lokal dengan transmigran pendatang.

Kedua : Tingkat rentang jarak sosial antara petani transmigran lokal dengan petani transmigran pendatang berpengaruh nyata terhadap tingkat keharmonisan interaksi sosial diantara mereka. Semakin positif/kecil rentang jarak sosial yang tercipta maka semakin positif tingkat keharmonisan interaksi sosial diantara mereka.

Ketiga : Tingkat keharmonisan interaksi sosial antara petani transmigran lokal dengan petani transmigran pendatang tidak berpengaruh nyata terhadap tingkat kesejahteraan non materil petani transmigran lokal. Keempat : Tingkat keharmonisan interaksi sosial antara petani transmigran lokal dengan petani transmigran pendatang berpengaruh nyata terhadap tingkat serapan inovasi teknologi transmigran lokal dari transmigran pendatang.

Kelima : Tingkat serapan inovasi dari sesama petani berpengaruh nyata terhadap tingkat adopsi inovasi oleh petani transmigran lokal ; namun sikap petani terhadap kegiatan penyuluhan, kondisi internal petani dan tingkat ketersediaan lembaga pendukung usahatani tidak berpengaruh nyata terhadap adopsi inovasi petani transmigran lokal.

Keenam : Secara simultan, variabel Tingkat serapan inovasi dari sesama petani, sikap petani terhadap kegiatan penyuluhan, kondisi internal petani dan tingkat ketersediaan lembaga pendukung usahatani menentukan sebesar 34,7\% tingkat adopsi inovasi oleh petani transmigran pendatang sedangkan 65,3 \% disebabkan oleh variabel lainnya yang tidak diteliti dalam penelitian ini.

Ketujuh : Tingkat adopsi inovasi transmigran lokal berpengaruh nyata terhadap tingkat pendapatan usahatani mereka.

Kedelapan : Tingkat adopsi inovasi transmigran lokal tidak berpengaruh nyata terhadap tingkat pendapatan total mereka, hal ini antara lain karena proporsi tingkat pendapatan dari non usahatani jauh lebih tinggi daripada tingkat pendapatan dari usahatani.

Kesembilan : Terdapat perbedaan nyata antara pendapatan usahatani petani transmigran lokal sebelum mengikuti program transmigrasi dengan sesudah mengikuti program transmigrasi, dimana rerata pendapatan usahatani mereka sebelum mengikuti transmigrasi lebih tinggi dari rerata pendapatan usahatani setelah mengikuti program transmigrasi.

\section{Daftar Pustaka}

Abustam, Muhammad Idrus. 1990. Gerak Penduduk, Pembangunan dan Perubahan Sosial. Jakarta : UI Press.

Akib Tuwo, M. 2001. Alokasi Sumberdaya dan Faktor Sosial Ekonomi yang Mempengaruhi Penerapan Teknologi Serta Hubungannya dengan Kualitas Hidup Petani. Disertasi Doktor, Program Pascasarjana Universitas Padjadjaran, Bandung (Tidak dipublikasikan)

Azwar, Syaifuddin, 1995. Sikap Manusia Teori dan Pengukurannya. Yogyakarta : Pustaka Pelajar.

Baruadi, Rudin .1993. Faktor-faktor yang mempengaruhi Sikap dan Adopsi Petani Terhadap Modernisasi Pertanian Padi Sawah dan Petani Tambak di Sulawesi Selatan, Disertasi Doktor, Pascasarjana, Universitas Padjadjaran. (Tidak dipublikasikan).

Bayo Ala, Andre. 1996. Kemiskinan dan Strategi Memerangi Kemiskinan. Yogyakarta: Liberty.

Benyamine, M. 2009. Reinkarnasi Tanah Hak Ulayat Masyarakat Dayak Kalimantan Barat. Materi Seminar Kearifan Lokal Masyarakat Adat. Pontianak: Universitas Tanjungpura.

Fliegel, F. C., J. E. Kivlin and G. S. Sekhon.1977. Message Distorsion and Diffusion of Innovation in Northern India. New Delhi : Sociologis Nuralis.

Hair, J.F., Anderson, R.E., Tatham, R.L., dan Black, W.C., 1998. Multivariate Data Analysis (5th Edition), UK: Prentice Hall International.

Ikrosnaeni, S. 2006. Pendapatan Petani Ladang Berpindah di Sekitar Hak Pengusahaan Hutan PT. Suka Jaya Makmur Kalimantan Barat. Thesis, Departemen Manajemen Hutan Fakultas Kehutanan IPB (Tidak dipublikasikan).

Krisnadi, Johan. 2010. Beberapa Kendala dalam Upaya Peningkatan Taraf Hidup Masyarakat Desa Hutan di Kalimantan Barat. Materi Seminar. Pontianak: Universitas Tanjungpura.

Kusnendi, 2007. Model-model Persamaan Struktural Satu dan Multigroup Sampel Dengan LISREL. Bandung: Alfabeta.

Kuswandie. 2010. Praktek Pertanian Ladang Berpindah di Kecamatan Nanga Ketungau Kabupaten Sintang Provinsi Kalimantan Barat. Laporan Penelitian. Sintang : LSM Gema Rasa.

Kuswantinah. 2005. Hubungan Antara Produktivitas dan Luas Lahan dengan Pendapatan Petani Kentang di Pagar Alam Provinsi Sumatera Selatan. Disertasi Doktor, Program Pascasarjana Universitas Padjadjaran, Bandung (Tidak dipublikasikan).

Land, Kenneth C., 1969. Principles of Path Analysis. In Edgar F. Borgatta (editor). Sociological Methodology, San Francisco: Jossey-Bass Behavioral Science.

Michael R. Dove. 1985. Peranan Kebudayaan Tradisional Indonesia dalam Modernisasi. Jakarta :Yayasan Obor Indonesia.

Mosher A.T. .1966. Menggerakan dan Membangun Pertanian (Terjemahan). Jakarta: Yasaguna.

Paturochman, Maman. 2012. Penentuan Jumlah dan Teknik Pengambilan Sampel. Bandung : Fakultas Peternakan Univ. Padjadjaran.

Petebang, Edi. 1999. Ketergantungan Masyarakat Dayak Terhadap Hutan. Jurnal Antropologi Sosial. Volume 93. Nomor 3.

Riduwan, 2008. Cara Menggunakan dan Memaknai Analisis Jalur (Path Analysis). Bandung: Alfabeta.

Rogers, EM, and FF. Shoemaker. 1971. Communication of Innovation. Newyork: Free Press.

Suandi dan Damayanti, Yusma. 2010. Analisis Disparitas Kesejahteraan Ekonomi Subjektif Keluarga Petani di Daerah Perdesaan Provinsi Jambi Berdasarkan Agroekologi Wilayah. Jurnal Unijam. Volume 12. Nomor 1. Universitas Jambi.

Sudjarwo .1997. Pola Interaksi Sosial Masyarakat Majemuk dalam Tiga Jalur Hubungan Sosial Untuk Mencapai Integrasi Bangsa. Disertasi Doktor, Pascasarjana, Universitas, Padjadjaran. (Tidak dipublikasikan).

Suharto, Edi, 2009. Kemiskinan dan Perlindungan Sosial di Indonesia. Bandung : Alfabeta.

Suharto, Edi, 2003. Kemiskinan dan Keberfungsian Sosial. Laporan Penelitian. Kerjasama LSP STKS dengan Pusat Penelitian dan Pengembangan UKS Balatbangsos.

Van den Ban, A. W, Hawkins, H.S. 1999. Penyuluhan Pertanian. Yogyakarta: Kanisius. 